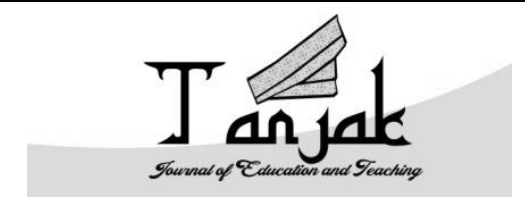

Tanjak: Journal of Education and Teaching

ISSN 2716-4098 (P) 2720-8966 (O)

Volume 1 Nomor 2, 2020

\title{
PENDIDIKAN KELUARGA DAN PARTISIPASI MASYARAKAT PADA PROGRAM KELUARGA BERENCANA DI MASA PANDEMI COVID- 19 DESA KERANDIN KECAMATAN LINGGA TIMUR KABUPATEN LINGGA
}

\author{
Romi Aqmal ${ }^{1}$ \\ STAIN Sultan Abdurrahman Kepulauan Riau, romi_aqmal@stainkepri.ac.id
}

DOI: https://doi.org/10.35961/tanjak.v1i2.159

\begin{abstract}
Abstrak
Pendidikan keluarga adalah segala usaha yang dilakukan oleh orang tua berupa pembiasaan dan improvisasi untuk membantu perkembangan pribadi anak. Sehingga pendidikan keluarga menjadi sangat penting dalam upaya perencanaan keluarga dan pembangunan keluarga. Peningkatan partisipasi program KB di masa pandemi Covid19 merupakan langkah penting dalam pengendalian penduduk dan masalah-masalah sosial lainnya. Penelitian dilakukan bertujuan untuk mengetahui tingkat partisipasi masyaraka terhadap program tersebut dimasa pandemi covid-19 melalui pendekatan perspektif sosiologis. Konsep teori yang digunakan yaitu menurut Kaho (1988:115) menegaskan partisipasi masyarakat dalam 4 hal, pertama dalam proses pembuatan keputusan, dalam pelaksanaan, pemanfaatan hasil dan evaluasi. Jenis penelitian yang digunakan adalah penelitian diskriptif dengan pendekatan kualitatif. Hasil dari penelitian ini menggambarkan bahwa PUS (Pasangn Usia Subur) dan masyarakat setempat kurang berpartisipasi aktif dalam menjalankan program KB karena faktor pengalaman, efek samping, kebudayaan dan keyakinan. Kondisi ini dapat dilihat dari data capaian target nasional yang belum memenuhi yaitu hanya 53,91 $\%$, permasalahan lainnya yaitu kurangnya sosialisasi yang diberikan, faktor pendidikan, pendampingan, serta kurangnya kerja sama dengan tokoh masyarakat atau keagamaan setempat.
\end{abstract}

Kata kunci: Partisipasi, Pendidikan Keluarga, 


\begin{abstract}
Family education is all the efforts made by parents in the form of habituation and improvisation to help the child's personal development. So that family education is very important in family planning and family development efforts. Increasing participation in family planning programs during the Covid-19 pandemic is an important step in controlling population and other social problems. The research was conducted to determine the level of community participation in the program during the Covid-19 pandemic through a sociological perspective approach. The theoretical concept used is according to Kaho (1988: 115) emphasizes community participation in 4 things, first in the decision-making process, in implementation, utilization of results and evaluation. This type of research is descriptive research with a qualitative approach. The results of this study illustrate that PUS (fertile age pairs) and local communities do not participate actively in running the family planning program due to experience, side effects, culture and beliefs. This condition can be seen from the data on the achievement of the national target which has not met, namely only $53.91 \%$, other problems are the lack of socialization provided, factors of education, assistance, and lack of cooperation with local community or religious leaders.
\end{abstract}

Keywords: Participation, Family education

\title{
Pendahuluan
}

Pendidikan Keluarga merupakan bagian terpenting dalam menunjang keberhasilan program keluarga berencana ini, karena hal ini menjadi ukuran pokok dalam perencanaan pembangunan rumah tangga, selanjutnya tentu tergantung dari aktif atau tidak aktifnya partisipasi mereka dalam mensukseskan program tersebut. Sebagaimana diuraikan dalam konsep pendidikan keluarga yang dikemukakan oleh Abdullah (2003:232) pendidikan keluarga adalah segala usaha yang dilakukan oleh orang tua berupa pembiasaan dan improvisasi untuk membantu perkembangan pribadi anak. Selain dari peran orang tua tersebut, untuk memaksimalkan program keluarga ini perlu adanya kepercayaan diri, tanggung jawab sosial, peranan pemimpin, prakarsa dan kepekaan masyarakat maka salah satu unsur peran serta adalah kemauan dan kemampuan masyarakat (Sulaiman. 1985:39). Sehingga dalam posisi ini peran aktif masyarakat sangat penting artinya bagi kelancaran dan keberhasilan program tersebut dan tercapainya tujuan secara mantap.

Menurut Professor DR. dr. Dwiana Ocvyanti SpOG, MPH, Koordinator Pendidikan Himpunan Obstetri dan Ginekologi Sosial Indonesia (HOGSI)-POGI, masih rendahnya pemahaman masyarakat secara umum tentang konsep perencanaan keluarga menjadi salah satu masalah dalam program perencanaan keluarga. Kepala BKKBN dr.Hasto Wardoyo Sp.OG. menuturkan "Pelayanan $\mathrm{KB}$ yang sangat berdampak akibat wabah Covid-19 ini dikarenakan KB sendiri pelayanannya yang ada sekarang adalah dengan baksos, sosialisasi oleh Penyuluh Keluarga Berencana, dan juga kader-kader. Jadi sangat full kontak atau people to people contact atau person to person. Sehingga ketika ada physical distancing atau social distancing maka jelas akan menurun pelayanan itu," jelas Ketua BKKBN Hasto Wardoyo dalam webinar "Antisipasi Baby Boom Pasca Pandemi”. Hal itu berimbas pada penurunan peserta KB, menurut Hasto terdapat penurunan peserta KB pada bulan Maret 2020 apabila dibandingkan dengan bulan Februari 2020 di seluruh Indonesia. Pemakaian IUD pada Februari 2020 sejumlah 36.155 turun menjadi 23.383. Sedangkan implan dari 81.062 menjadi 51.536, suntik dari 524.989 menjadi 341.109, pil 251.619 menjadi 146.767, kondom dari 31.502 menjadi 19.583, MOP dari 2.283 menjadi 1.196, dan MOW dari 13.571 menjadi 8.093. (https:/ / www.voaindonesia.com) 
Kondisi ini menimbulkan kekhawatiran akan adanya lonjakan kelahiran bayi atau baby boom pasca pandemi Covid-19. Keadaan yang demikian itu bila sering terjadi maka akan berakibat kurang lancarnya kegiatan sesuai dengan rencana sehingga menyulitkan usaha pencapaian tujuan program secara utuh dan mantap (Sutopo, 1996: 132). Sehingga peran aktif pemerintah dan masyarakat sangat diperlukan dalam memaksimal pencapaian target pengguna program KB yang belum mencapai target secara Nasional yaitu 60\% dalam setiap wilayah atau desa, khususnya di Desa Kerandin di Kecamatan Lingga Timur yang masih belum mencapai target Nasional yang diharapkan. Sebagaimana dijelaskan oleh Kaho (1988:115) menegaskan bahwa partisipasi masyarakat dapat terjadi dalam 4 hal yaitu: 1) Partisipasi dalam proses pembuatan keputusan, 2) Partisipasi dalam pelaksanaan, 3) Partisipasi dalam pemanfaatan, 4) Partisipasi dalam evaluasi.

Menyikapi situasi saat ini, masyarakat diwajibkan untuk "stay at home" Untuk memutuskan mata rantai penyebaran virus covid-19 ini, maka peluang untuk bersama keluarga dan berhubung biologis antar suami istri sangat intens bisa terjadi dan membuka peluang selebar lebarnya akan peningkatan angka kelahiran bayi atau bisa kita sebutkan sebagai antisipasi baby boom pasca pandemi Covid-19. Berdasarkan data di lapangan diketahui bahwa pencapaian tertinggi pengguna $\mathrm{KB}$ adalah Desa Sungai Pinang dengan KK 322 jiwa, PUS 192 jiwa, yang menggunakan KB berjumlah 139 jiwa atau 72,4 persen; kemudian diikuti Desa Kudung dengan KK 240 jiwa, PUS 137 jiwa, yang menggunakan KB berjumlah 95 jiwa atau 69,34 persen; kemudian diikuti lagi Desa Pekaka dengan KK 166 jiwa, PUS 89 jiwa, yang menggunakan KB berjumlah 55 jiwa atau 61,8 persen; Desa Bukit Langkap dengan KK 114 jiwa, PUS 75 jiwa, jumlah pengguna KB 45 jiwa atau 60,00 persen; dan Desa Keton dengan KK 95 jiwa, PUS 46 jiwa, jumlah pengguna KB 26 jiwa atau 56,52 persen; Selanjutnya Desa terendah pencapaian pengguna KB di Kecamatan Lingga Timur adalah Desa Kerandin yaitu dengan KK 222 jiwa, PUS 115 jiwa, dengan jumlah pengguna 62 jiwa atau 53,91 persen. Data ini terus mengalami penurunan seiring dengan waktu. (Sumber : Badan Pemberdayaan Perempuan dan Keluarga Berencana Kab. Lingga).

Partisipasi masyarakat menurut Isbandi (2007:27) adalah :"Keikutsertaan masyarakat dalam proses pengidentifikasian masalah dan potensi yang ada di masyarakat, pemilihan dan pengambilan keputusan tentang alternatif solusi untuk menangani masalah, pelaksanaan upaya mengatasi masalah, dan keterlibatan masyarakat dalam proses mengevaluasi perubahan yang terjadi”. Definisi partisipasi dalam pembahasan ini diartikan sebagai peran serta masyarakat dalam program Keluarga berencana yang diselenggarakan oleh pemerintah sedangkan masyarakat mengambil sebagian kewajiban yang menjadi tanggung jawab pemerintah, dan masyarakat mendapatkan manfaat dan keuntungan dari programtersebut.

Selain beberapa indikator permasalahan diatas yang menguraikan tentang persoalan terhadap partisipasi masyarakat didalam program Keluarga tersebut, ada hal lain yang menajdi pertimbangan penting bagi peneliti untuk mendalami kalian ini yaitu kondisi giografis social ekonomi, pendidikan dan budaya yang berkembang dimasyarakat yang berpengaruh langsung terhadap perkembangan program KB di masyarakat Desa Kerandin. Selain itu Desa Kerandin merupakan daerah ekstransmigrasi yang diperkirakan dengan pertumbuhan penduduk pada masa itu meningkat secara drastis sehingga tentu akan berpengaruh pada sektor perekonomian masyarakat, social kultur, sarana dan prasana yang tersedia serta pertimbangan kodisi sosial lainnya seperi persepsi masyarakat tentang program $\mathrm{KB}$, ideologi yang 
dipegang masyarakat dan tingkat pendidikan pasangan keluarga sehingga sangat mempengaruhi partisipasi masyarakat dalam kesuksesan program keluarga berencana ini.

\section{Metode Penelitian}

Penelitian ini dilakukan dengan menggunakan pendekatan deskriftip kualitatif yaitu berusaha untuk menjelaskan gambaran yang nyata tentang partisipasi masyarakat dalam program Keluarga Berencana melalui pendekatan perspektif sosiologis di Desa Kerandin Kecamatan Lingga Timur Kabupaten Lingga. Populasi yang diambil adalah masyarakat Desa kerandin Kecamtan Lingga Timur Kabupaten Lingga yang termasuk dalam PUS yaitu 115 jiwa pasangan keluarga dengan Sampel sebanyak 20 orang, yaitu 9 PUS yang masih aktif dalam program KB, 9 PUS yang sudah tidak aktif lagi menggunakan KB dan ditambah 2 orang sebagai Kei informan yaitu motivator KB dan Bidan yang bertugas di puskesmas Desa Kerandin.

Analisis data yang digunakan adalah analisis data kualitatif, yang mana dijelaskan oleh Moleong (1991:35), menyatakan bahwa "analisis data kualitatif adalah proses pengorganisasian dan pengurutan data dedalam pola dan kategori serta satuan uraian dasar, sehingga dapat dikemukakan tema seperti yang disarankan oleh data”. Sedangkan langkah-langkah analisa yang dilakukan adalah : menelaah semua data yang tersedia dari berbagai sumber terkait dengan program keluarga berencana dan programprogram pendidikan keluarga yang telah terlibat oleh masyarakat, reduksi data yang dilakukan dengan membuat abstraksi, menyusun kedalam satuan-satuan, pengkategorian data sambil membuat koding, mengadakan pemeriksaan keabsahan data dan penapsiran data secara deskriptif.

Untuk itu data-data yang terkumpul baik data primer maupun data skunder yang diperoleh melalui wawancara, maka akan diorganisir dan disusun. Setelah disusun kemudian dilakukan penafsiran dan pembahasan terhadap data yang dikemukan itu. Penyelidikan terhadap suatu peristiwa disini hanya sebatas untuk melihat bagaimana partisipasi masyarakat dalam program keluarga berencana di Desa Kerandin Kecamatan Lingga Timur kabupaten Lingga.

\section{Hasil dan Pembahasan}

\section{Karakteristik Responden Berdasarkan Tingkat Usia}

Usia dalam penelitian sangat mempengaruhi seseorang atau setiap pasangan keluarga untuk melakukan dan menjalakan program KB, karena usia kesuburan secara normal setiap pasangan keluarga baik baru menikah maupun yang sudah lama menikah adalah 15 - 49 tahun.

\section{Tabel IV.2}

\section{Karakteristik Responden Berdasarkan Tingkat Usia}

\begin{tabular}{|c|c|c|c|}
\hline No. & Umur & $\begin{array}{c}\text { Jumlah } \\
\text { (Orang) }\end{array}$ & $\begin{array}{c}\text { Persentase } \\
\text { (\%) }\end{array}$ \\
\hline 1. & $20-25$ & 4 & 20 \\
\hline 2. & $26-30$ & 6 & 30 \\
\hline 3. & $31-35$ & 8 & 40 \\
\hline 4. & $36-40$ & 2 & 10 \\
\hline & Jumlah & $\mathbf{2 0}$ & $\mathbf{1 0 0}$ \\
\hline
\end{tabular}


Sumber data : Hasil Penelitian Wawancara, 2020

Dari tabel IV.2 diatas, terlihat bahwa responden terbanyak adalah berumur 31 samapai dengan 35 tahun yaitu terdapat 8 orang atau sebesar 40 persen, selanjutnya berumur 26 samapai dengan 30 tahun yaitu berjumlah 6 orang atau sebesar 30 persen, selanjutnya responden yang berumur 20 samapai dengan 25 tahun yaitu berjumlah 4 orang atau sebesar 20 persen, berikutnya responden yang berumur 36 samapi dengan 45 tahun berjumlah 2 orang atau 10 persen.

Berdasarkan uraian tingkat umur responden diatas, dari jumlah keseluruahn informan bahwa pada tingkat umur 20 - 25 tahun dan 26 - 30 tahun merupakan responden PUS yang dominannya adalah akseptor KB aktif dan responden dari tingkat umur 31 - 35 dan 36 - 40 tahun meruakan responden PUS yang sudah tidak aktif lagi sebagai akseptor KB. Maka pada tingkat usia kesuburan responden diatas baik akseptor yang aktif maupun yang tidak aktif lagi menjadi akseptor KB diharapakan dapat memberikan penilaian secara objektif dalam penelitian ini mengenai partisipasi masyarakat Desa Kerandin Kecamatan Lingga Timur Kabupaten Lingga dalam program KB.

\section{Analisis Tingkat Partisipasi Masyarakat Dalam Program Keluarga Berencana Melalui pendidikan keluarga di Era Pandemi Covid-19 Desa Kerandin Kecamatan Lingga Timur Kabupaten Lingga}

Partisipasi masyarakat Desa Kerandin Kecamatan Lingga Timur dalam program Keluarga Berencana mempunyai fungsi yaitu untuk meciptakan kemudahan pada masyarakat dalam mengatur dan merencanakan masa depan keluarga, baik dalam merencanakan keturunan maupun merencanakan pendidikan anak kedepannya dengan menyesuaikan kodisi perekonomian keluarga agar harapan yang diinginkan bersema tercapai sesuai dengan tujuan masing - masing keluarga. Untuk melihat partisipasi masyarakat tersebut terjadi dalam 4 hal yaitu pertama, partisipasi dalam proses pembuatan keputusan; kedua, partisipasi dalam pelaksanaan; ketiga, partisipasi dalam pemanfaatan; ke empat, partisipasi dalam evaluasi. Sebagaimana yang diungkapakan Kaho diatas, tentang partisipasi masyarakat dapat diuraikan sebagai berikut:

1. Partisipasi masyarakat dalam proses pembuatan keputusan, partisipasi masyarakat pada tahap ini sangat mendasar sekali dimana masyarakat dalam keadaan yang paling ideal dalam membuat keputusan yang menyangkut nasib mereka dimana semakin besar kemampuan untuk menentukan nasib sendiri maka semakin besar pula partisipasi masyarakat dalam pembangunan. Idealnya, masyarakat hanya akan terlibat dalam aktifitas selanjutnya apabila mereka merasa ikut andil dalam menentukan apa yang akan dilaksanakan.

2. Partisipasi dalam pelaksanaan, masyarakat melalui keikutsertaannya dalam memberikan kontribusi guna menunjang pelaksanaan pembangunan yang berwujud tenaga, uang, barang, material sesuai kemampuan yang dimiliki setiap orang.

3. Partisipasi dalam pemanfaatan hasil, anggota masyarakat berhak untuk berpartisipasi dalam menikmati setiap usaha bersama yang ada dan dapat menikmatinya secara adil. Adil disini adalah setiap orang berhak mendapatkan bagiannya sesuai dengan pengorbanannya yang dilihat dari 3 segi, yaitu : aspek manfaat materialnya (material benefit), manfaat solusinya (Social benefit), dan manfaat pribadi (Personal benefit).

4. Sedangkan partisipasi dalam evaluasi, setiap penyelenggaraan, apapun dalam kehiduapan bersama hanya dapat dinilai berhasil apabila dapat memberikan manfaat bagi masyarakat maka 
sepantasnyalah masyarakat diberi kesempatan menilai hasil yang telah dicapai dalam hal ini. Masyarakat dapat dijadikan sebagai hakim yang adil dan jujur dalam menilai hasil yang ada.

\section{Proses Pembuatan Keputusan dalam Program KB}

Pengambilan keputusan dalam sebuah rumah tangga maupun didalam kelompok masyarakat sangat diperlukan sehingga mencapai kesepakatan bersama untuk mencapai tujuan kebahagiaan secara jasmani maupun rohani dari sebuah keluarga yang bahagia ataupun kesejahteraan didalam kelompok masyarakat dalam memlihara kerukuran hidup bersama. Proses pembuatan keputusan dalam program KB oleh setiap pasangan keluarga Desa Kerandin Kecamatan Lingga Timur dapat dilihat dari beberapa dimensi yaitu, mulai dari mendengarkan penyuluhan mengenai metode kontrasepsi didalam program $\mathrm{KB}$, mengajukan pertanyaan mengenai metode kontrasepsi yang diinginkan, dan memutusakan untuk mejadi akseptor KB dengan metode kontrasepsi yang pilih.

Hasil analisis yang ditemukan dilapangan bahwa yang sudah berkeluarga dan termasuk dalam Pasangan Usia Subur (PUS) tidak ikut serta mengadiri sosialisasi yang diberikan oleh pihak yang bersangkutan didalam program KB ini yaitu oleh Badan Pemberdayaan Perempuan dan Keluarga Berencana (BPPKB) Kabupaten Lingga yang mengenai tujuan dan manfaat dari program KB tersebut, selain itu warga Desa Kerandin Kecamatan Lingga Timur yang tergolong dalam pasangan usia subur juga hanya mendapatkan informasi mengenai program KB ini dari keterangan akseptor KB lain nya dan sebagian mendapatkan informasi dari bidan atau motivator KB pada saat melakukan KB. Serta yang menentukan untuk menjadi akseptor KB didalam keluarga diambil atau diputuskan secara pribadi oleh istri mereka dan suami hanya sebatas mengetahui yang mana rata-rata akseptor $\mathrm{KB}$ memilih $\mathrm{KB}$ suntik yang 3 bulan karena merasa lebih aman dan praktis di banding jenis KB lainnya.

\section{Pelaksanaan Pada Program Keluarga Berencana}

Partisipasi dimana masyarakat melalui keikutsertaannya dalam memberikan kontribusi guna menunjang pelaksanaan kegiatan program Keluarga Berencana melalui jenis-jenis alat kontrasepsi yang ditawarkan dalam mengatur dan membina rumah tangga serta untuk menekan angka kematian ibu dan bayi dan juga mengatasi masalah ledakan penduduk yang tidak seimbang. Sehingga diperlukan adanya kesadaran dan kerjasama dari masyarakat untuk mensukseskan Keluarga Berencana yang diprogram kan oleh pemerintah ini, khususnya untuk program Keluarga Berencana di Desa Kerandin Kecamtan Lingga Timur yang sudah berkembang cukup lama dan belum memenuhi target Nasional yang diharapkan yaitu $60 \%$.

Partisipasi dalam pelaksanaan program Keluarga Berencana oleh setiap Pasangan Usia Subur (PUS) pada masyarakat Desa Kerandin dapat dilihat dari berbagai dimensi yaitu melihat kelebihan yang dirasakan selama mejadi akseptor KB, melihat kelemahan atau kekurangan yang dirasakan akseptor KB, mendapati kendala-kendala yang dialami akseptor pada saat pelaksanaan KB tersebut, serta melihat bagaimana proses yang dilalui para akseptor KB ketika memilih alat kontrasepsi yang cocok untuk digunakan.

Hasil analisis ditemukan bahwa Pasangan Usia Subur warga Desa Kerandin Kecamatan Lingga Timur hanya merasa kelebihan menjadi akseptor KB itu sekedar untuk mengatur jarak kelahiran anak dan merasa lebih banyak mendapat kerugian atau kelemahan dari KB tersebut yaitu efek yang terjadi pada tubub akseptor seperti bercak-bercak hitam, gemuk, pusing dan lain sebagainya. Sehingga 
permasalahan ini yang membuat partisipasi masyarakat dalam program $\mathrm{KB}$ menjadi rendah dan cendrung tidak maksimal menjalankannya khususnya bagi PUS.

\section{Pemanfaatan hasil program KB}

Partisipasi dalam pemanfaatan hasil program Keluarga Berencana merupakan salah satu keikutsertaan masyarakat dalam memanfaatkan hasil dari program Keluarga Berencana di daerah mereka tersebut. anggota masyarakat berhak untuk berpartisipasi dalam menikmati setiap usaha bersama yang ada dan dapat menikmatinya secara adil. Adil disini adalah setiap orang berhak mendapatkan bagiannya sesuai dengan pengorbanannya yang dilihat dari 3 segi, yaitu : aspek manfaat materialnya (material benefit), manfaat solusinya (Social benefit), dan manfaat pribadi (Personal benefit).

Ikut serta masyarakat tidak hanya melaksanakan suatu kegiatan melainkan ikut memanfaatkannya. Program KB tidak hanya diperuntukan untuk mereka yang sudah memiliki anak saja melainkan juga bagi mereka yang belum memiliki anak agar merencanakan keturunan mereka sesuai yang dengan keadaan dan harapan yang diinginkan. Hasil analisis yang didapatkan dilapangan bahwa pemanfaatan hasil program Keluarga Berencana oleh warga Desa Kerandin Kecamatan Lingga Timur dapat dilihat dari beberapa dimensi yaitu menggunakan $\mathrm{KB}$ secara teratur dan mandiri sesuai dengan petunjuk dokter atau bidan, dan mendapati manfaat yang diinginkan sesuai dengan harapan keluarga.

\section{Evaluasi dari hasil program keluarga berencana (KB)}

Evaluasi merupakan proses penyederhanaan dalam memberikan atau menetapkan nilai kepada sejumlah kegiatan, keputusan dan sebagainya. Evaluasi dari hasil program Keluarga Berencana (KB) oleh warga Desa Kerandin Kecamatan Lingga Timur dapat dilihat dari beberapa dimensi yaitu mengontrol kesehatan secara teratur dan mandiri, mendapat hasil yang diharapkan selama menjadi akseptor KB dan menganjurkan pada warga lainnya untuk menjadi akseptor KB.

Pada sub indikator ini, dapat disimpulkan bahwa masing-masing Pasangan Usia Subur (PUS) akseptor KB Desa Kerandin Kecamatan Lingga Timur tidak ikut serta mengevaluasi kegiatan program $\mathrm{KB}$, yaitu dapat dilihat dalam hal tidak berjalannya kegiatan yang diselenggarakan didalam program KB seperti Bina Keluarga Balita (BKB), Bina Keluarga Remaja (BKR), dan Bina Keluarga Lansia (BKL), selain itu warga menyambut positif program KB yang diberikan oleh pemerintah hanya saja tidak merasa puas dengan apa yang mereka rasakan serta masih sering muncul persepsi-persepsi negatif terhadap program KB tersebut hal ini dapat dilihat dengan masih rendahnya akseptor KB yang ada di Desa Kerandin Kecamatan Lingga Timur yang belum mecapai target Nasional.

\section{Faktor pendorong dan penghambat peningkatan partisipasi masyarakat dalam program Keluarga Berencana Di Masa Pandemi Covid_19 di Desa Kerandin Kecamatan Lingga Timur Kabupaten Lingga.}

Faktor pendorong partisipasi masyarakat dalam program Keluarga Berencana (KB) dimasa Pandemi Covid_19 Desa Kerandin Kecamatan Lingga Timur Kabupaten Lingga yaitu bahwa para ibuibu yang sudah berkeluarga dan dalam masa usia subur ingin mengatur jarak anak-anaknya agar lebih mudah mengatur dan mengontrol pendapatan dan pengeluaran, keadaan dan harapan untuk sang buah 
hati kedepannya yaitu dengan mengatur jarak anak pertama dengan yang kedua, anak kedua dan anak ketiga dan seterusnya tergantung setiap pasangan keluarga yang mengingin anak didalam rumah tangganya, selain itu pada program KB ini juga banyak ditawarkan KB gratis seperti implant, spiral, pil $\mathrm{KB}$ dan Kondom, untuk meringankan beban keluarga bagi yang kondisi perekonomiannya tidak mampu dengan harapan agar setiap pasangan keluarga mau ikut program KB khususnya bagi Pasangan Usia Subur (PUS).

Faktor penghambat partisipasi masyarakat dalam program Keluarga Berencana (KB) di masa Pandemi Covid_19 Desa Kerandin Kecamatan Lingga Timur Kabupaten Lingga yaitu pertama dari segi agama yang mensunahkan manusia untuk memperbanyak keturunan, kemudian dari segi pelaksanaan sering mengalami ketidak cocokan dari KB yang digunakan yang menimbulkan efek negatif pada tubuh akseptor seperti flek-flek hitam pada wajah, tubuh menjadi gemuk tanpa diketahui pasti apa penyebabnya, selanjutnya dari segi status wanita itu sendiri yaitu praturan yang mengharuskan persetujuan dari suami sebelum layanan $\mathrm{KB}$ diperoleh, serta persepi-persepsi yang negatif pada program KB tersebut hingga akhirnya membuat setiap pasangan baik itu pada pasangan muda maupun pasangan yang sudah lama menikah ragu dan cemas untuk mengikuti program KB yang di programkan oleh pemerintah ini yang sekarang dijalankan oleh Badan Pemberdayaan Perempuan dan Keluarga Berencana (BPPKB).

\section{Kesimpulan}

Hasil dari penelitian ini dengan judul pendidikan keluarga dan partisipasi masyarakat pada program keluarga berencana pada masa pandemi covid-19 di Desa Kerandin Kecamatan Lingga Timur Kabupaten Lingga menejelaskan bahwa pendidikan-pendidikan keluarga yang berikan kepada masyarakat belum sepenuhnya dipahami dan diterima oleh masing-masing anggota keluarga, dan belum semua anggota keluarga mendapatkan pendidikan atau sosialisasi tersebut dikarenakan kesibukan mereka dalam bekerja dan keluar kota, partisipasi masyarakat yang seharusnya diperlukan seperti tokohtokoh adat dan tokoh agama masih belum maksimal, serta kendala-kendala lain sebagai aseptor KB juga menjadi faktor pendorong dan penghambat dari keberhasilan tingkat partisipasi masyarakat tersbut terhadap program keluarga berencana yaitu 53,91\% dari $70 \%$ target yang ingin dicapai.

Adapun hasil kesimpulan dari 4 (empat) indikator partisipasi masyarakat dari program keluarga berencana diatas adalah:

1. Proses pembuatan keputusan

Pasangan Usia Subur (PUS) tidak ikut serta mengadiri sosialisasi yang diberikan oleh pihak yang bersangkutan didalam program KB ini yaitu oleh Badan Pemberdayaan Perempuan dan Keluarga Berencana (BPPKB) Kabupaten Lingga yang mengenai tujuan dan manfaat dari program KB tersebut, selain itu warga Desa Kerandin Kecamatan Lingga Timur yang tergolong dalam pasangan usia subur juga hanya mendapatkan informasi mengenai program KB ini dari keterangan akseptor $\mathrm{KB}$ lain nya dan sebagian mendapatkan informasi dari bidan atau motivator $\mathrm{KB}$ pada saat melakukan KB. Serta yang menentukan untuk menjadi akseptor KB didalam keluarga diambil atau diputuskan secara pribadi oleh istri mereka dan suami hanya sebatas mengetahui yang mana rata-rata akseptor $\mathrm{KB}$ memilih $\mathrm{KB}$ suntik yang 3 bulan karena merasa lebih aman dan praktis di banding jenis KB lainnya. 
2. Pelaksanaan dalam program

Pada indikator ini, dapat disimpulkan bahwa Pasangan Usia Subur warga Desa Kerandin Kecamatan Lingga Timur hanya merasa kelebihan menjadi akseptor KB itu sekedar untuk mengatur jarak kelahiran anak dan merasa lebih banyak mendapat kerugian atau kelemahan dari KB tersebut yaitu efek yang terjadi pada tubub akseptor seperti bercak-bercak hitam, gemuk, pusing dan lain sebagainya. Sehingga permasalahan ini yang membuat partisipasi masyarakat dalam program KB menjadi rendah dan cendrung tidak maksimal menjalankannya khususnya bagi PUS.

3. Pemanfaatan hasil dalam program KB

Pada sub indikator ini, dapat disimpulkan bahwa masing-masing anggota keluarga tidak ikut serta mengajak, mengontrol hasi yang dirasakan saat menajalnkan program KB secara rutin ke warga lainnya, hal ini terlihat bahwa warga atau aksepor menilai bahwa program KB ini hanya merupakan pilihan setiap masing-masing keluarga sehingga mereka merasa tidak perlu ikut campur dalam urusan rumah tangga orang lain. Selain itu PUS tidak maksimal menjalankan program KB, hal ini terlihat bahwa para akseptor KB tidak rutin mengonsumsi KB yang mereka gunakan yaitu pada saat mereka tidak melakukan hubungan suami istri.

4. Evaluasi dari hasil program KB

Pada sub indikator ini, dapat disimpulkan bahwa masing-masing Pasangan Usia Subur (PUS) akseptor KB Desa Kerandin Kecamatan Lingga Timur tidak ikut serta mengevaluasi kegiatan program KB, yaitu dapat dilihat dalam hal tidak berjalannya kegiatan yang diselenggarakan didalam program KB seperti Bina Keluarga Balita (BKB), Bina Keluarga Remaja (BKR), dan Bina Keluarga Lansia (BKL), selain itu warga menyambut positif program KB yang diberikan oleh pemerintah hanya saja tidak merasa puas dengan apa yang mereka rasakan serta masih sering muncul persepsipersepsi negatif terhadap program $\mathrm{KB}$ tersebut hal ini dapat dilihat dengan masih rendahnya akseptor KB yang ada di Desa Kerandin Kecamatan Lingga Timur yang belum mecapai target Nasional.

\section{Ucapan Terimakasih}

Ucapan terima kasih pasa pemerintahan Desa Kerandin, BKKBN Kabupaten Lingga, para pendamping dan Tokoh masyarakat yang sudah memfasilitasi penelitian ini, dan saran agar dapat selalu memperhatikan protokol kesehatan dimasa pandemi covid-19 ini, selanjutnya bias memberikan tempat (lokasi) untuk kegiatan program Keluarga Berencana (KB) agar program Bina Keluarga Balita (BKB) yang pernah sempat aktif bisa dilanjutkan kembali khususnya bagi PUS yang memiliki anak balita agar mendapat pengetahuan yang lebih untuk perkemabangan otak ana

Ucapan terimakasih juga deiberikan kepada pengelola jurnal STAIN Sultan Abdurrahman Kepulauan Riau bersama Tim yang telah membantu dalam proses penerbitan jurnal hingga hasil penelitian dapat diterbitkan di jurnal Open Jurnal System TANJAK STAIN Sultan Abdurrahman Kepulauan Riau Tahun 2020. 


\section{Referensi}

Abdullah, M. Imron, (2003) Pendidikan Keluarga Bagi Anak, Cirebon : Lektur

Ahmadi, A. (1991). Sosiologi Pendidikan. Jakarta: Rineka Cipta.

Arikunto, Suharsimi. 2006. Prosedur Penelitian, Suatu Pendekatan Praktik. Jakarta : Rineka Cipta

Atmodiwirjo, Ediasri dan Patmonodewo, S. 1981-1990. Bahan Pelatihan BKB. Perwakilan BPKBN Provinsi Kepri.

Handayani, Sri, S.Si.T. 2010. Buku Ajar Pelayanan Keluarga Berencana. Yogyakarta : Pustaka Rihama.

Horton, P,B dan Hunt, Chester. 1984. Sosiologi. Jakarta: Erlangga.

Isbandi Rukminto Adi. 2007. Perencanaan Partisipatoris Berbasis Aset Komunitas : dari Pemikiran Menuju Penerapan. Depok : FISIP UI Press.

J. Goode, William. 2007. Sosiologi Keluarga. Jakarta : PT Bumi Aksara

Khairuddin. 2002. Sosiologi Keluarga. Yogyakarta : Liberty

Megawangi, R. (1993). Keluarga dan Peningkatan Kualitas Sumberdaya Manusia dalam Rangka Menyongsong Abad ke-21.

Megawangi, R. (1999). Membiarkan Berbeda: Sudut Pandang Baru tentang Relasi Gende Bandung: Mizan.

Moleong, lexy. 2007. Metode penelitian Kualitatif, Bandung : PT Remaja Rosdakaya.

Mustofa, Bisri. 2008. Metode Menulis Skripsi dan Tesis, Yogyakarta : Optimus.

Parwitaningsih. 2005. Pengantar Sosiologi. Jakarta : Universitas Terbuka

Rudyanto. (2007). Psikologi Perkembangan Anak dan Remaja (Gunarsa dan Gunarsa). Jakarta: PT BPK Gunung Mulia.

Saifuddin, Abdul Bari Prof. dr. SpOG(K), MPH, dkk. 2006. Buku Panduan Praktis Pelayanan Kontrasepsi. Jakarta : Yayasan Bina Pustaka Sarwono Prawirohardjo

Soelaeman, MI.(1994). Pendidikan Dalam Keluarga. Bandung : IKIP

Soehartono, Irwan. 2004. Metode Penelitian Sosial. Bandung. PT. Remaja Rosdakarya.

Soekanto, Soerjono. 1982. Sosiologi Suatu Pengantar. Jakarta : Raja Grafindo Persada.

Sunarto, Drs, MPd. 2012. Materi Bina Keluarga Lansia (BKL). Perwakilan BPKBN Provinsi Kepri.

Suparjan, Suyanto, Hempri. 2003. Pengembangan Masyarakat : Dari Pembangunan Sampai Pemberdayaan. Yogyakarta: Aditya Media 